\title{
Vizuální akty ve výukové komunikaci ${ }^{1}$
}

\author{
Roman Švaříček ${ }^{a}$, Zuzana Šalamounováb \\ ${ }^{a}$ Masarykova univerzita, Filozofická fakulta, Ústav pedagogických věd \\ ${ }^{\mathrm{b}}$ Masarykova univerzita, Pedagogická fakulta, Katedra pedagogiky
}

\begin{abstract}
Redakci zasláno 16. 9. 2012 / upravená verze obdržena 9. 11. 2012 / k uveřejnění přijato
\end{abstract}
15. 11.2012

\begin{abstract}
Abstrakt: Předložená empirická studie pojednává o tom, jaké funkce ve výukové komunikaci mezi učiteli a jejich žáky zastávají vizuální významové akty, tj. sdělení viditelná aktérům komunikace, jež jim přičítají určitý význam. Výsledky, které studie zprostředkovává, vycházejí z kvalitativní analýzy 32 videonahrávek vyučovacích hodin humanitních předmětů na druhém stupni základních škol. Vizuální významové akty jsou nejprve diferencovány na tematické, které zobrazují události, objekty či myšlenky spjaté s tématem komunikace, a interaktivní, jež slouží jako sdělení kontaktní. $V$ kontextu vyučovacích hodin jsou pak tematické akty prezentovány jako nástroj konceptualizace výukových obsahů, zatímco akty interaktivní zobrazeny jakožto mechanismus napomáhající uspořádání výukové komunikace. Přestože vizuální významové akty zastávají analogické funkce a mnohdy vytvářejí tytéž vzorce, je zřejmé, že jejich podoba je výrazně individualizovaná a lze ji chápat jako znak profesní identity učitele.
\end{abstract}

Klíčová slova: výuková komunikace, vizuální významový akt, verbální komunikace, neverbální komunikace, IRF struktura

\section{1 Úvod}

Školní třídu můžeme označit jako kulturu v mnoha smyslech auditivní. Učitelé žákům ve výuce převypravují podstatu aktuálního učiva, žáci se na výkladu podílejí doplňováním informací jim dostupných. Ve snaze popsat komunikaci ve školní třídě se proto předmětem zkoumání stává primárně orální verbální komunikace² (viz napřs. Mehan, 1979; Cazden, 1988; Nystrand et al., 1997; Alexander, 2006). Tuto tendenci můžeme vidět i na dlouholeté tradici komunikačních studií, kde se předmětem zkoumání stávají především

1 Tento článek vznikl v rámci projektu Učitel a žáci v dialogickém vyučování financovaného Grantovou agenturou České republiky (GA13-23578S) a Škola: výzkum vnitřních procesů a vnějších podmínek jejího fungování financovaného Grantovou agenturou České republiky (GA406/09/H040). Autoři děkují za poskytnutou podporu.

2 Pojmem verbální komunikace budeme v textu nadále označovat pouze orální komunikaci, nikoli psaný text. 
textové transkripty s přepisy uskutečněných komunikačních výměn. Sdělení mimoverbální - tedy to, co je ve školní třídě viditelné a nikoli slyšitelné -, jsou oproti tomu mnohdy nepozorována a zůstávají spíše na okraji výzkumného zájmu (Roth, 2001, s. 365). Realizovaná zkoumání této orientace pak bývají vystavěna především na dekontextualizovaném fyzickém popisu některého z aktérů komunikace - dozvídáme se například, že určité držení těla může za jistých okolností naznačovat submitivitu či naopak dominanci učitele, avšak dané scény bývají zcela vytrženy z kontextu výuky, což značně problematizuje jejich interpretaci a její spolehlivost (srov. např. Neil, 1991).

V rámci dosavadního zkoumání výukové komunikace jsme se co možná nejpodrobněji věnovali struktuře výukové komunikace. Vycházeli jsme primárně z komunikace verbální, přesto však nebylo možné opomenout dění mimoslovní (Šed'ová, Švařriček, \& Šalamounová, 2012). Typickými př́íkladem je mechanismus učitelova vyvolávání žáků, které může být realizováno pokývnutím, pohledem, pohybem dlaně, ukázáním prstem či krátkým předsunutím brady, a přitom ve všech těchto podobách plní tutéž funkci, jako kdyby ze strany učitele zaznělo: „Co si myslís ty, Lucko?“ Stejným způsobem jsme museli přistupovat také k mechanismu zamlčeného hodnocení, které bylo nutné interpretovat bud' až z nadcházejícího verbálního sdělení (položení další otázky je současně potvrzením, že předcházející žákovská odpověd' byla přijata jako správná, více in Šed’ová \& Švaříček, 2010), nebo právě z mimoverbálního komunikačního jednání učitele. Např́íklad krátké přikývnutí po tom, co žák odpověděl na učitelovu otázku, je sice v rovině deskripce zcela svébytným procesem, nicméně z hlediska své funkce obsahuje stejnou zprávu jako položení další otázky. Z uvedených př́́kladů je zřejmé, že neverbální komunikace, kterou lze zjednodušeně definovat jako „komunikaci beze slov“ (DeVito, 2008, s. 152), hraje ve výukové komunikaci taktéž významnou roli, a proto jsme se rozhodli věnovat se jí podrobněji. ${ }^{3}$

Neverbální komunikace ve školní třídě výuce může sloužit různým cílům. Například Klinzing a Jackson (1987) popisují, že neverbální komunikace: (a) může učiteli pomoci vyjádřit jeho očekávání a postoje k žákům; (b) může být nástrojem, jehož prostřednictvím učitel řídí interakci ve třídě (například skrze pohyb, oční kontakt či změnu hlasu); (c) má ilustrativní funkci; (d) umožňuje žákům (zejména prostřednictvím gest a tělesného vyjádření) lépe pochopit verbální sdělení učitele. Zejména poslední dva zmíněné cíle přitom jasně poukazují na to, že je nemožné zkoumat neverbální komunikaci,

3 O neverbální komunikaci viz Hackl a Hummel (2011). 
aniž bychom vedle sledování pohybů, držení těla či výrazů tváře poslouchali také verbální projev učitele, což prokážeme záhy. Spíše se ukazuje nutnost zkoumání obou složek jak verbálních, tak neverbálních sdělení v jejich koexistenci, což prokazují také experimenty, které dokládají, že opomenutí jedné složky zásadně změní význam komunikační situace (např. Reinhard \& Sporer, 2008).

Tato skutečnost nás vedla k rozhodnutí, že budeme sledovat tzv. významové akty spojující jak verbální, tak neverbální komunikaci, a to vždy v návaznosti na kontext, $v$ němž se odehrávají. Termín významový akt je v této souvislosti používán $s$ ohledem na to, že ne veškerému komunikačnímu jednání je ze strany komunikujících přičítán určitý význam. ${ }^{4}$ Orientujeme se proto pouze na ta sdělení, jimž je z hlediska jejich příjemců přisuzován určitý význam, a která tak mohou být označena za významové akty. Místo o neverbální komunikaci - zajímá nás ostatně vždy také verbální stránka věci - přitom hovoříme o vizuální složce významového aktu (Bavelas \& Chovil, 2000). Termínem vizuální významové akty zde tedy odkazujeme na ta sdělení, která jsou viditelná aktérům komunikace, již jim přičítají určitý význam, a která mohou být ve vzájemném vztahu s paralelně neseným verbálním sdělením. ${ }^{5}$ Právě zkoumání vizuálních sdělení ve školní třídě totiž umožňuje jiným způsobem nahlédnout výukovou komunikaci a současně vyvodit určité implikace pro zkoumání její verbální složky. Smyslem našeho zkoumání je také identifikovat, jakým způsobem jsou vizuální sdělení utvářena.

\section{Cesta od neverbální komunikace k vizuálním aktům}

Rozhodnutí zaměřit se na vizuální sdělení nebylo náhodné a vycházelo z obeznámení se s teoretickým konceptem neverbální komunikace, který je pro náš cíl nepříliš užitečný, což se nyní pokusíme ilustrovat.

4 Jako př́klad uved'me situaci, kdy žáci píší test a jejich učitelka se podívá na hodinky. Tuto situaci můžeme interpretovat např́klad tak, že kontroluje, aby žáci nepracovali déle, než byl předem domluvený čas. Ze strany učitelky se však nejedná o komunikační sdělení určené pro žáky. Pokud by však učitelka ve stejné chvíli řekla například nahlas: „Tak“ a v momentě, kdy by k ní žáci zvedli hlavu, se výrazně podívala na hodinky, je to již významové sdělení pro žáky, kteří tak dostávají např́iklad informaci, že čas, který měli na práci s testem, se blíží konci.

5 Naše použití termínu vizuální však není shodné se známou teorií viditelného vyučování a učení (visible learning), kterou popisuje Hattie (2009). Pro něj je viditelné učení takové, kde je žákům stanoven explicitní cíl, pokud je pro žáky tento cíl adekvátní výzvou, pokud učitel i žáci hledají, do jaké míry je cíl splněn, když je přítomna zpětná vazba a když jsou aktéři reálně zaníceně zapojeni. 
Neverbální komunikace bývá typologizována v závislosti na kanálu, který je v rámci komunikace použit, a v návaznosti na funkci, kterou dané komunikační sdělení plní. Typologizací podle užitého komunikačního kanálu rozlišujeme mimické signály, pohledy očí, zaujímání prostorových pozic, postoje těla, doteky atd. (Schrober \& Clark, 1989). Př́kladem může být alternace signálu pro vyvolání konkrétního žáka. Pokud má učitelka, která je zvyklá vyvolávat zamířením ukazováčku, mezi prsty kř́ídu, vyvolá pokynutím celé dlaně. V situaci, kdy v rukou drží knihu nebo se opírá o stůl, a nemůže tedy signál vyslat rukou, pokývne směrem ke zvolenému žákovi bradou. Jak však z tohoto př́́kladu vyplývá, z hlediska své komunikační funkce má rozdělení podle kanálu, jímž je sdělení realizováno, minimální vypovídající hodnotu.

Z hlediska funkce neverbální komunikace pak hovoříme o gestech, která vyjadřují určitá slova či slovní spojení a jejichž častým př́kladem je situace, v níž učitelé na odpověd' žáka reagují gestem připomínajícím špetku či trošku, tj. vytvořením malého prostoru ve tvaru protáhlého písmene U mezi ukazováčkem a palcem, čímž sdělují, že odpověd' ještě není úplně přesná, je kousek vedle odpovědi požadované. Další kategorií jsou ilustrátory, které doprovázejí a ilustrují slovní sdělení. Příznak doprovázení naznačuje, že se jedná o sdělení redundantní, kterými není sdělováno nic víc, než co je paralelně sdělováno slovy (učitelka např́klad řekne: „Otevřete si sešity“ a současně udělá imaginární pohyb představující tuto aktivitu). Může se však jednat také o sdělení neredundantní, která verbálně sdělovanému přidávají další významovou rovinu. Frekventovaným projevem tohoto typu je deixe (srov. Roth, 2001), tedy ukazování a odkazování (například sdělení ilustrující větu: „Podívejme se na toto slovo“ je doprovázeno poukázáním na konkrétní slovo napsané na tabuli). Další skupinou jsou regulátory, které se vztahují ke komunikačnímu procesu a jeho kontrole. Typickým př́kladem regulátoru, který bývá uváděn v kontextu školní třídy, je situace, kdy si učitel přiloží ukazováček kolmo přes ústa, aby sdělil, že se žáci mají utišit. ${ }^{6}$ Posledními dvěma skupinami jsou afektivní projevy, jež slouží k vyjádření emocí a které jsme si ilustrovali příkladem o vyjádření sympatií ze strany učitele, a adaptéry, které uspokojují určitou potřebu mluvčího/adresáta - jedná se např́íklad o pohrávání si s fixem či upravování hodinek ze strany učitele.

Na základě našich dat přitom nemůžeme potvrdit, že se jedná o univerzální, objektivizovanou, obecně sdílenou podobu tohoto sdělení. Většina učitelů z našeho vzorku pro tuto zprávu naopak využívá svůj vlastní, individuální signál (srov. Wulf, 2010) - např́iklad pozici podobnou řeckému písmenu $\psi$, v níž učitel má obě ruce v pravém úhlu od těla s lokty pokrčenými vzhůru opět v pravém úhlu a dlaněmi ke třídě, kterými dělá krátký kmitavý pohyb. 
Při převedení do komunikační reality je však také tato diferenciace problematická, což můžeme zachytit na několika situacích z našich dat. Jakým způsobem např́klad interpretovat situaci, kdy učitelka ve výuce zvedne ukazováček směrem vzhůru? Může se jednat jednak o gesto se zprávou Pozor! (frekventovaně využívané např. ve chvíli, kdy učitel sděluje klíčové informace $\mathrm{k}$ látce), stejně jako o regulátor, jímž učitelka napomíná žáky a signalizuje, že mají být potichu, nebo o ilustrátor, kterým se učitelka snaží žáky dovést například ke slovu strop (zde hovoříme o situaci, kdy učitelka chce, aby žáci našli odpovídající sousloví ke slovu lustr a oni nemohou přijít na sousloví stropní svítidlo).

Tento př́klad fyzického jednání s trojím možným sémantickým obsahem je ilustrací přirovnání, v níž jsou neverbální sdělení připodobňována k polysémním slovům, která bez kontextu taktéž nemají jediný význam (Bavelas \& Chovil, 2000). Z této skutečnosti pak vychází tři teze, z nichž je podle našeho názoru nutné při zkoumání neverbální dimenze výukové komunikace vyjít. Zaprvé, odlišení gesta od regulátoru, ilustrátoru, či dokonce náhodného pohybu není závislé na vlastním fyzickém jednání, ale na úsudku o jeho lingvistickém významu (Bavelas, 1994). Klíčová je pro nás tedy otázka, jaký význam v sobě dané komunikační sdělení nese, nikoli jakou má podobu.

Zadruhé, pokud chceme relevantně interpretovat význam určitého sdělení, musíme dobře porozumět také kontextu komunikační situace, nikoli pouze izolovanému sdělení.Všechny složky sdělení,zvolené slovo, stejnějako použité gesto, jsou totiž účastníky interakce bezprostřednímu komunikačnímu kontextu přizpůsobeny (Bavelas et al., 2011, s. 50).

Zatřetí, pokud chceme porozumět komunikačnímu kontextu, musíme porozumět také obsahu a významu verbálního sdělení, pokud probíhá paralelně s neverbálním sdělením, nebot' přestože mohou být analyzovány izolovaně, fungují verbální a neverbální dimenze komunikace většinou jako dvě části jednoho a téhož lingvistického procesu (McNeill, 1992). Zejména v kontextu školní třídy, kde je nutné sdělit velké množství informací více adresátům v poměrně krátkém čase, sice může být verbálně a neverbálně vysíláno více nesouvisejících zpráv (Neill, 1991). Učitelka například verbálně vysvětluje dějepisnou látku a paralelně vysílá mimoslovní signály, jimiž žáky napomíná $\mathrm{k}$ tichosti. 


\section{Vizuální významové akty}

Jednotkou našeho zkoumání jsou vizuální složky významových aktů, o kterých hovoříme jako o vizuálních významových aktech (srov. Bavelas \& Chovil, 2000). Vizuální významové akty definujeme jako viditelné jednání, které může probíhat paralelně verbální komunikací. Slyšitelné i viditelné informace obsažené ve významovém aktu jsou provázány, a proto je nutné význam daného aktu interpretovat s ohledem na obě tyto dimenze. Nemůžeme ale tvrdit, že vše, co je ve tř́dě viditelné, je interpretováno jako významotvorné. Jak např́klad v souvislosti s gesty podotýká Roth (2001, s. 369), „zatímco všechna gesta jsou pohyby rukou, ne všechny pohyby rukou jsou chápána jako gesta“. To v kontextu našeho zkoumání znamená, že ne všechno vizuální jednání učitele je zamýšleno a interpretováno jako významový akt s komunikativní funkcí.

Bevalesová a Chovilová (2000) uvádějí následující charakteristiky vizuálních významových aktů: (a) pro jejich přítomnost je klíčová existence vizuálního kanálu mezi komunikujícími - míra výskytu vizuálních sdělení se totiž snižuje úměrně s poklesem šance na to, že je př́ijemce uvidí a bude je tak moci dekódovat; (b) lze je chápat jako analogově dekódovaná sdělení; (c) jejich význam je možné interpretovat s ohledem na kontext probíhající promluvy; (d) jsou integrovány do probíhající verbální promluvy, at' už do této promluvy přinášejí určité nové (verbálně nevyjádřené) informace, nebo vytváŕí pouze určitý zrcadlový obraz toho, co již bylo řečeno slovy (a jsou tedy tzv. redundantní). Právě skutečnost, že vizuální významové akty nemusí být redundantní, pro zkoumání komunikace ve školní třídě znamená, že ve chvíli, kdy je komunikace zkoumána pouze na základě transkriptů, které nezahrnují textové „překlady“7 vztahující se k vizuální rovině komunikace, sdělení zprostředkovaná touto cestou se mohou zcela vytratit. $V$ této studii se proto podíváme „mezi řádky“ transkriptů a pokusíme se najít, co se skrývá mezi slovy.

Již jsme uvedli, že vizuální významové akty jsou kontextově vázané. Provázanost $\mathrm{s}$ kontextem komunikační situace však může probíhat dvěma různými cestami. Vizuální sdělení se může vztahovat bud' k předmětu aktuální promluvy, tedy k jeho obsahu, čímž navazuje na verbální složku, nebo k adresátovi promluvy, čímž dané vizuální sdělení překračuje hranice verbálního

7 Pojem „překlad“ zde používáme zcela záměrně, nebot’ vizuální a verbální sdělení jsou zcela odlišné kódy a jejich převedení z jednoho do druhého je vždy obtížné. 
obsahu. Podle tohoto klíče pak hovoříme o tematických vizuálních aktech, které zobrazují události, objekty či myšlenky přímo spjaté s tématem konverzace, a interaktivní vizuální akty, u nichž spojitost s tématem absentuje, nebot' slouží jako sdělení kontaktní (Bavelas, 1994). Pro lepší příklad si můžeme představit rybáře ukazujícího pažemi svůj bájný úlovek (tematický akt), či učitele vyvolávajícího žáka ukázáním pravé ruky (interaktivní akt). $\mathrm{V}$ tomto textu se budeme zabývat oběma typy vizuálních aktů.

Tematické vizuální akty jsou vedle verbální promluvy nejčastěji tvořeny pohyby rukou. Jejich prostřednictvím je možné přímo ukazovat na předmět promluvy nacházející se v daném fyzickém prostoru (pokud např́klad učitel hovoří o zárubních, ukáže na ně ve tř́dě, aby žákům ilustroval poměrně neznámý předmět promluvy), napodobit konkrétní předmět promluvy (ve chvíli, kdy učitelka hovoří o koleni na potrubí, kreslí je před sebou rukou), nebo dokonce demonstrovat určitou abstraktní entitu (ve výuce např́iklad učitelé často rukama vyjadřují plynutí času či provázání minulosti a přítomnosti). Tato vizualizace přitom má nezpochybnitelnou roli, nebot' spolu s verbální promluvou pomáhá utvářet nejen promluvu mluvčího, ale spoluutvářejí i jeho myšlení (McNeill, 1992). Zastánci této teze (viz Kita, 2000) tvrdí, že jak analytické myšlení (které je ve vztahu k řeči), tak prostorové a motorické myšlení (jež je ve vztahu s gestikou) umožňují mluvčímu lépe vyjádřit dané sdělení. Mluvčí totiž může využít dva kanály, které mají odlišné možnosti, co se týče konceptualizace informace, ve snaze vyjádřit ji pro posluchače. Tematické vizuální akty proto mohou přetvářet teoretické koncepty mluvčího do sémiotické podoby. Tematická vizuální sdělení nepoužívají s úspěchem jen učitelé takových „vizuálních předmětů“, jako je chemie, matematika a fyzika (Roth, 2001; Reynolds \& Reeve, 2002), ale pomáhají např́iklad také vědcům při společné práci vytvářet abstraktní teorie, jako je biochemická teorie molekul (Becvar, Hollan, \& Hutchins, 2005).

Oproti tomu interaktivní vizuální akty sdělení obohacují probíhající promluvu o celou řadu významů (Bavelas et al., 1995), jmenovitě např́íklad o informace, že mluvčí právě sdělil pointu své promluvy, že v jeho promluvě došlo $\mathrm{k}$ digresi a návratu $\mathrm{k}$ původní výkladové linii, že sdělení je eliptické a mluvčí ponechává na adresátovi, jak si dál obsah vyloží, že mluvčí vychází ze zkušenosti sdílené spolu s adresátem, že adresáta žádá o pomoc při nalezení vhodného slova na doplnění své promluvy, že od adresáta očekává potvrzení toho, co je mu sděleno, které by verbálně mohlo být přeloženo ve smyslu: „Že ano?" atd. 
Míra zastoupení interaktivních vizuálních aktů je závislá na zvolené komunikační formě. Zatímco v monologu je tematických vizuálních sdělení devětkrát více nežli interaktivních, při interaktivním komunikačním nastavení je jejich vzájemný poměr jedna ku třem (Bavelas et al., 1995, s. 400). Na základě našich předcházejících šetření ze školní třídy jsme přitom konstatovali, že výukový monolog, v němž učitel zprostředkovává tř́idě obsah aktuální látky, zastává ve vyučovacích hodinách pouze $4 \%$ veškeré komunikace ve školní třídě, zatímco formy interaktivní, v nichž se stř́ídá učitel a žáci, se vyskytují více než desetkrát více (podrobně in Šed’ová, Švaříček, \& Šalamounová, 2012, s. 50). Z toho vyplývá, že ve vyučovacích hodinách bychom vzhledem k jejich komunikačnímu uspořádání měli očekávat, že také interaktivní sdělení se dostávají ke slovu poměrně často a nejsou pouze okrajovým jevem.

\section{Metodologie výzkumného šetření}

V této studii se vracíme $\mathrm{k}$ datům sesbíraným v rámci projektu Komunikace ve školní tř́dě, který byl mezi roky 2009 až 2011 řešen na Ústavu pedagogických věd Filozofické fakulty Masarykovy univerzity. V rámci tohoto projektu jsme spolupracovali s šestnácti učiteli a tř́dními kolektivy druhého stupně čtyř jihomoravských základních škol. Jednalo se přitom o učitele humanitních předmětů - českého jazyka a literatury, dějepisu a občanské výchovy. Data byla sesbírána prostřednictvím dvou polostrukturovaných rozhovorů $\mathrm{s}$ každým z učitelů, několika pozorování a dvou videonahrávek vyučovací hodiny každého učitele a dotazníků pro žáky. V tomto textu budeme vycházet pouze z videozáznamů 32 vyučovacích hodin.

Když jsme na jaře roku 2010 sesbírali data, převedli jsme podle standardního postupu jejich obrazovou či zvukovou stopu do textové podoby, v níž jsme se snažili postihnout co nejpodrobnější obraz toho, co se v dané situaci odehrává. Přesto se však opakovaně stávalo, že co bylo zcela jasné při sledování vyučování, nebylo najednou tak jasné při pročítání datového transkriptu. Proto bylo nutné se vracet „za text“ a sledovat určité komunikační situace na videozáznamu. Základním materiálem pro další analýzy však vzhledem $\mathrm{k}$ našemu zaměření především na verbální dimenzi výukové komunikace zůstával datový transkript. V tomto článku se proto vracíme od textu k obrazu a naším primárním datovým zdrojem jsou videonahrávky.

S ohledem na základní roztřídění vizuálních významových aktů na interaktivní a tematické jsme si stanovili dvě základní výzkumné otázky: (1) Jakým 
způsobem se vizuální významové akty podílejí na utváření interakcí ve školní třídě? (2) Jakým způsobem je pomocí vizuálních významových aktů předáván kognitivní obsah?

Vzhledem k tomu, že gesta často nemají dlouhého trvání, rozdělili jsme výuku na jednotlivé vizuální významové akty, které trvají zhruba pět vteřin a obsahují interaktivní či tematické vizuální sdělení od učitele k žákům, případně následují žákovskou reakci. Významový vizuální akt obsahuje verbální sdělení učitele, gesto pažemi, mimiku ve tváři učitele a tělesný pohyb.

Každou z vyučovacích hodin jsme vždy nejprve nezávazně, bez vytváření kódů či mem, pozorovali, abychom se sžili s vizuální komunikací učitele a abychom si uvědomili následující reakce ze strany žáků. Při opětovném pozorování videonahrávek vyučovacích hodin jsme měli paralelně otevřený textový transkript. U každého projevu učitele, který by mohl být dekódován jako vizuální významový akt, jsme nahrávku zastavili a věnovali se jeho verbálnímu kontextu.

Ve shodě s postupem Bavelasové (1994, s. 211) jsme následně jednotlivé vizuální akty podle jejich vztahu k aktuálnímu tématu interpretovali jako interaktivní (nesouvisející s tématem výuky a orientováno na př́íjemce), nebo tematické (se vztahem k tématu výuky). Poté, co byl tímto způsobem roztříděn materiál ze všech vyučovacích hodin, byl ve snaze o zvýšení spolehlivosti analýzy dat celý postup zopakován. $\mathrm{V}$ předložené interpretaci přitom pracujeme pouze s těmi vizuálními akty, jež byly opakovaně interpretovány stejným způsobem (podotkněme, že se jednalo o většinu identifikovaných vizuálních sdělení). Namísto tradičních kódů jsme v rámci analýzy dané segmenty opatřili memy, obsáhlejšími poznámkami vztahujícími se k jednotlivým aktům či jejich částem. Součástí mem se stal také popis fyzického jednání a „překlad“ vizuálně vyjádřené informace do verbálního sdělení. Právě mema spolu s opakovaným zhlédnutím komunikačních situací se stala jádrem další analýzy a interpretace.

S ohledem na možný rozsah příspěvku se budeme zabývat popisem pouze dvou vyučujících, učitelky Johany ve výuce českého jazyka a učitelky Šárky v hodině literatury. Jednotlivé vizuální akty budeme prezentovat tak, že vždy ukážeme grafický náčrt daného vizuálního aktu a verbální transkript výukové komunikace. 


\section{$5 \quad$ Výsledky analýzy dat}

Popišme si nejdříve scénický prostor školní tř́idy. Mizanscéna vypadá následovně: třída je sálově uspořádána do čtyř až pěti řad vždy po trojici lavic, kde sedí jeden až dva žáci, zadní lavice často zůstávají neobsazené. Celá jedna stěna tř́́dy je prosklená, na její přední stěně je bílá, černá nebo zelená tabule, na třetí stěně, kudy se do třídy také vchází, zpravidla bývá jedna či více nástěnek. Zadní stěna skýtá určitou variabilitu - může být ponechána bílá, ale může být také pomalována žáky, případně o ni mohou být opřeny skř́ně, v nichž jsou pomůcky k výuce. Podlaha třídy je pokryta linoleem, na stropě jsou umístěny zářivky. Dominantní prvek ve tř́ídě tvoří katedra, dnes ve většině př́ípadů zastoupená učitelským stolem umístěným zpravidla před první lavicí u okna.

Ve chvíli, kdy zazvoní, se žáci (v závislosti na tom, jak znají svého učitele a jakou mají zkušenost s tím, po jak dlouhé době po zvonění do třídy přichází) různým tempem přesouvají na svá místa. Již první interakce, která mezi nimi a učitelem následně probíhá, má ritualizovanou vizuální podobu - máme tím na mysli vzájemný pozdrav učitelů a žáků, kterým bývá vyučovací hodina zpravidla dodnes otevřena.

Často následuje další vizuální významové sdělení, a to ze strany žáků. Pokud totiž na začátku hodiny chtějí učiteli něco sdělit, zůstanou i po „usazovacím“ signálu učitele stát a vyčkávají, až je osloví. Jedná se o další vizuální signál interaktivní povahy, který v tomto př́ípadě supluje vůbec nejvíce zastoupené interaktivní vizuální sdělení ve školní třídě, žákovské hlášení.

\subsection{Interaktivní vizuální akty}

Učitelka Johana ve své hodině literatury otevřela tematiku bible a ráda by se opřela o stávající znalosti žáků. Do třídy pokládá velmi širokou otázku po jakýchkoli znalostech, které již žáci o bibli mají. Ačkoli třída byla po celou dobu výuky až doposud velmi angažovaná, v momentě, kdy se učitelka zeptá, co si již o bibli ř́́kali, všichni žáci mlčí. O necelou minutu později je přitom zřejmé, že žáci mají o bibli poměrně značné povědomí. Proč tedy na otázku učitelky nikdo neodpovídal?

Při zkoumání podoby komunikačního uspořádání ve školní třídě je vždy jednou z prvních otázek, zda se jedná o komunikaci, na níž se verbálně podílí pouze učitel, nebo zda se strrídá se svými žáky, případně do jaké 
míry jsou oba zmíněné typy uspořádání zastoupeny. V závislosti na tom odlišujeme komunikační uspořádání monologické a interaktivní. ${ }^{8}$ Již od 70. let minulého století se přitom opakovaně prokazuje, že převažující je interaktivní nastavení komunikace (např. Flanders, 1970), které bývá nejčastěji organizováno v podobě trojčlenné struktury, jež se označuje jako IRF struktura a skládá se z otázky učitele, odpovědi žáka a navazující zpětné vazby učitele (např. Mehan, 1979; Cazden, 1988). Klasickým vodítkem, které vede (žáky i pozorovatele) k rozhodnutí, kdy monologická pasáž přechází v interaktivní, proto bývá otázka, již učitel do třídy položí a na niž očekává odpověd', tedy první ze tří složek IRF struktury.

Ve výuce však zaznívá mnohem více otázek, než kolik je určeno k zodpovězení žáky. Učitelé mnohdy pokládají otázky řečnické, kterými se snaží učinit svůj monolog posluchačsky atraktivnější a budit dojem kontaktovosti se svým publikem. Mnohé otázky určené k zodpovězení žáky na druhou stranu charakter otázky nemají a jsou realizovány v podobě určitých konstatování ve tvaru oznamovacích vět (Švaříček, 2011a). Žáci přesto vědí, kdy otázka není otázkou v běžném slova smyslu a kdy se naopak otevírá prostor pro jejich participaci na výukové komunikaci. Stejně jako je totiž podle určitého schématu organizována verbální komunikace, je také vizuální komunikace učitelů uspořádána podle určitého vzorce ovlivňujícího vedle IRF struktury celou výukovou komunikaci. $\mathrm{V}$ tomto vzorci můžeme identifikovat tři typy vizuálních aktů: výklad učitele, dialog učitele a žáků a návrat k výkladu učitele. Vizuální akty budeme ilustrovat na případu vizuální komunikace učitelky Johany. Jedná se o ukázky z hodiny českého jazyka, v níž učitelka s žáky opakuje téma obohacování slovní zásoby a procvičuje látku archaismů, historismů a neologismů.

\footnotetext{
Důvody, proč nepoužíváme termín dialogické uspořádání, dobře popisuje např. Alexander (2006), podle něhož je interaktivní uspořádání charakteristické pouze střídáním replik jednotlivých mluvčích, zatímco dialogická komunikace znamená také střridání různých mentálních perspektiv, reciprocitu mluvčích a vytváření nového sémantického prostoru pro všechny zúčastněné.
} 
Vizuální akt č. 1: Výklad učitele ${ }^{9}$

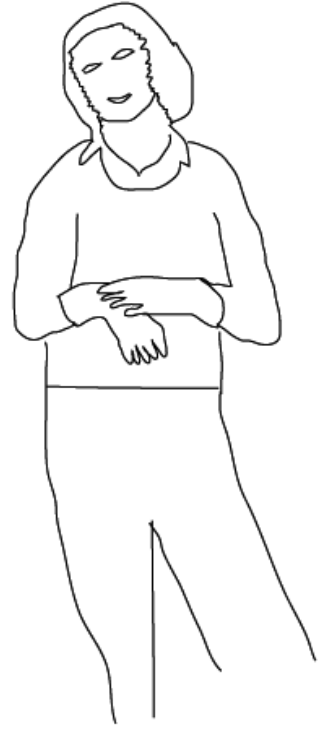

U: Archaismus je slovo, třeba lučba, to znamená, že v tom, mmm, dejme tomu v tom patnáctém šestnáctém století, se používalo a ted' používáme také toto slovo, ale ve znění chemie třeba, že? Anebo třeba bradýř jsme si ř́kali, holič a tak dále, ano? Čili to jsou takzvané archaismy.

Vizuální akt zachycuje vizuální sdělení, které vysílá učitelka Johana ve chvíli, kdy komunikační situaci ve tř́dě dominuje jakožto jediná legitimní mluvčí. Jedná se o moment, kdy učitelka třídě uvádí příklady archaismů a na těchto příkladech vysvětluje jejich princip. Stojí při tom na začátku stupínku, kde se pohybuje po ose, která začíná vedle katedry a končí před prostřední lavicí, a dívá se po třídě, aniž by dlouho setrvávala pohledem na kterémkoli z žáků. Výchozí pozici rukou vidíme na obrázku. Levá dlaň se zpravidla dotýká zápěstí pravé ruky, dlaně jsou natočeny směrem k tělu, a učitelka tak pomyslně vytváří menší uzavřený prostor pro sebe samu a svůj výklad. Žáci vědí, že v této fázi výuky je prostor pro ni jakožto jedinou mluvčí, zatímco oni se na situaci podílejí z pozice posluchačủ. Učitelka si tímto postojem ve výuce často udržuje svůj komunikační prostor.

Popis vizuálního aktu má vždy čtyři části: (a) název vizuálního aktu, (b) snímek z videonahrávky překreslený v grafickém programu, (c) napravo od snímku je přepis odehrávajícího se významového aktu, přičemž slovo či slovní spojení, které je vyznačeno tučně, označuje moment, který je zachycen vizuální ukázkou, a (d) interpretací daného vizuálního aktu dole. 


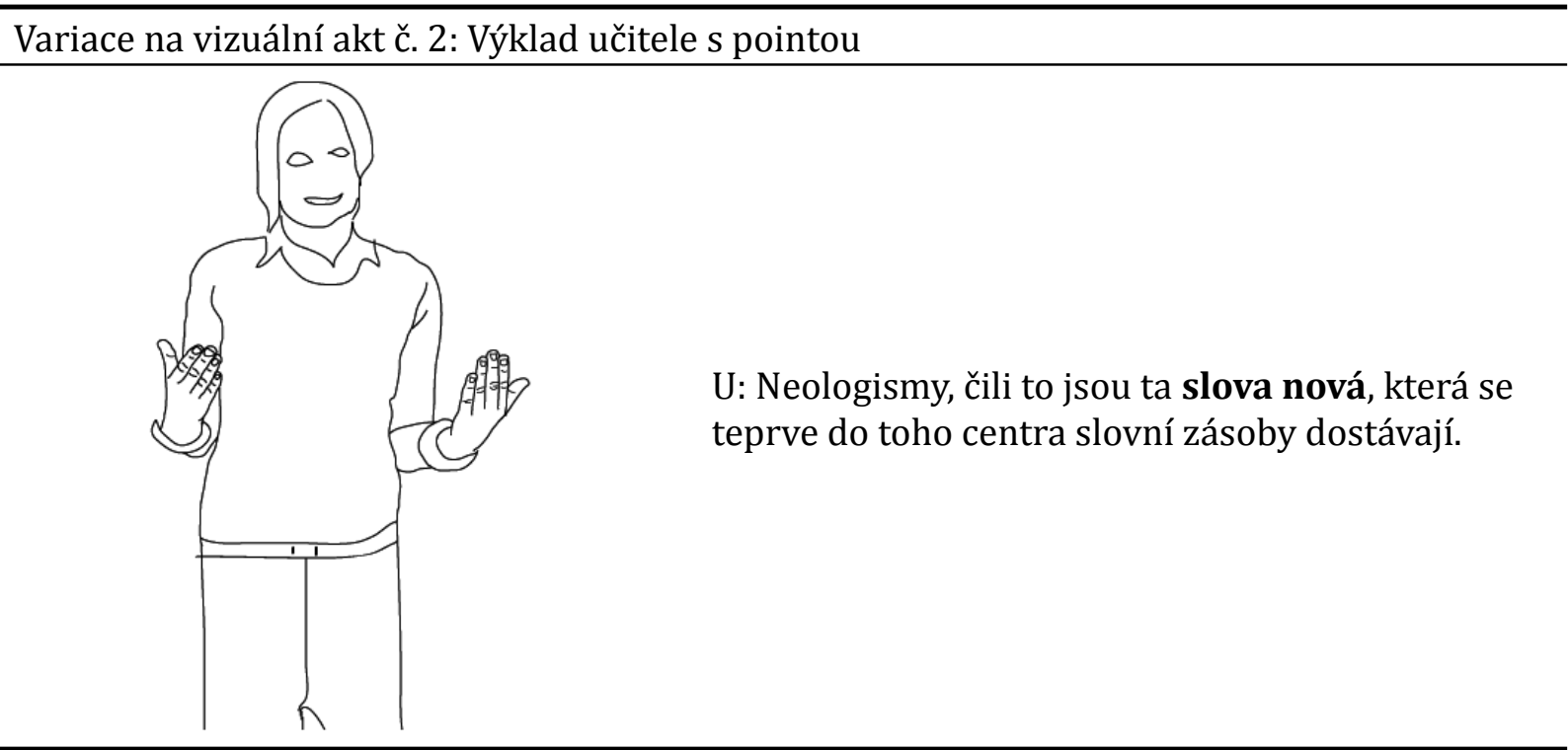

Vizuální sdělení označující fázi výuky, v níž probíhá výklad, variuje ve chvíli, kdy se učitelka Johana dostává ke stručné pointě. Tato situace nastává vzápětí po situaci zachycené $\mathrm{v}$ předcházejícím vizuálním aktu. Učitelka hovoří o neologismech, které může jednoduše a stručně definovat jako „nová slova“. Ve chvíli, kdy učitelka může vysvětlit podstatu určitého učiva pomocí jednoho či dvou slov, jako tomu je zde, mění se pozice jejích rukou, které se rozpojují a otáčí dlaněmi vzhůru a současně k tělu. Mohli bychom říci, že gesto symbolizuje určité předávání „daru“ vědění od učitelky k žákům. Učitelka vizuálně sděluje jednak to, že právě toto je pointa části výkladu, a zároveň stále mírí dlaněmi na sebe, mluvčí situace a garanta předkládaného sdělení.

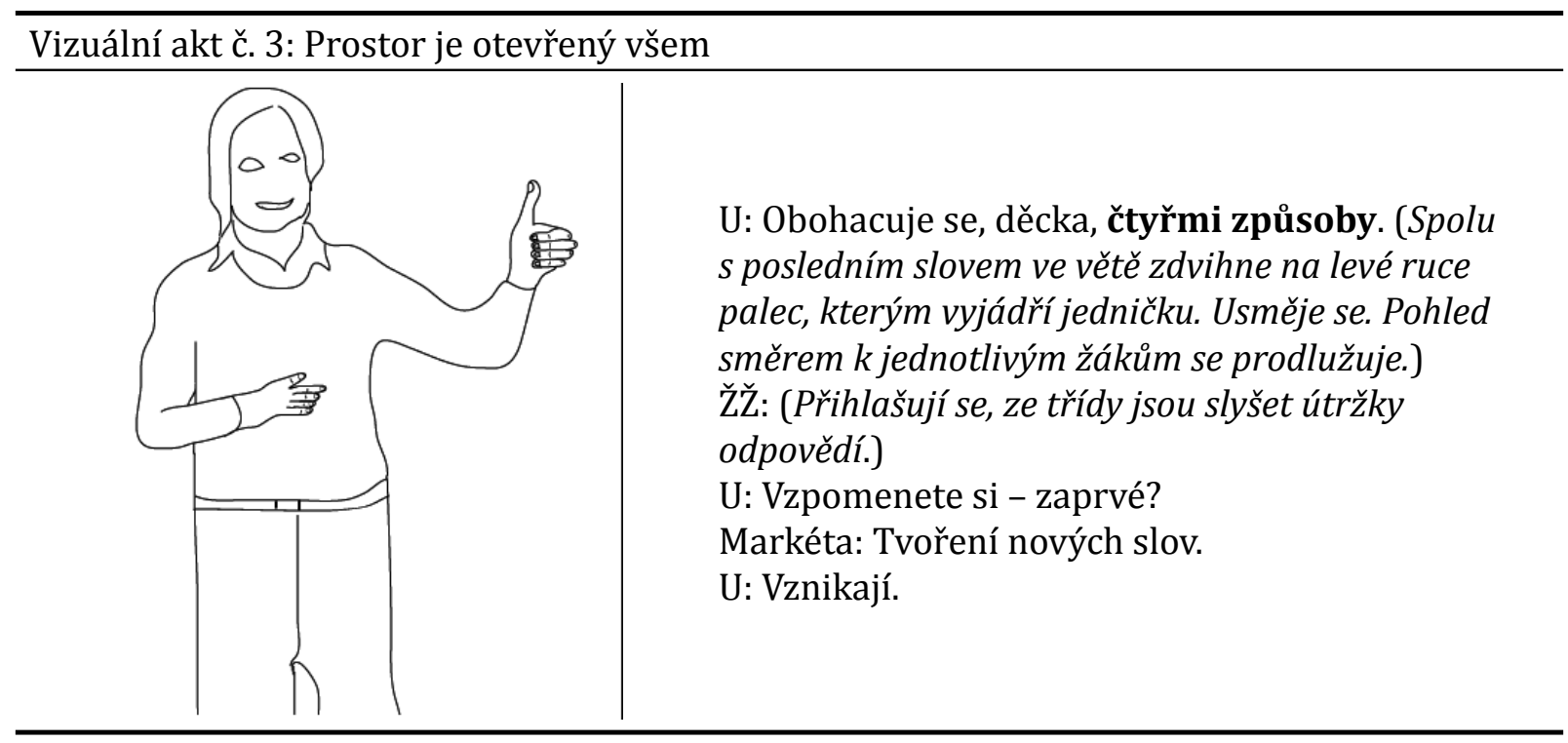


Sdělení, které bylo pro vizuální komunikaci klíčové ve fázi výkladu, je zcela opuštěno ve chvíli, kdy se mění uspořádání výukové komunikace a učitelka třídu převádí do IRF struktury. Těsně před vyslovením samotné otázky: „Vzpomenete si - zaprvé?“, která již náleží do interaktivní fáze výuky, učitelka odpočítáváním na palci demonstruje, že nyní se bude řešit první ze čtyř způsobů. Samo vypočítávání odpovědí však ještě není signálem k tomu, že je ze strany žáků očekávána odpověd'. Učitelka však současně stejnou rukou rozevírá prostor, který byl doposud ohraničen (vizuálně i verbálně) pouze pro ni samotnou. Právě ono uvolnění prostoru je u učitelky Johany vizuálním signálem, který mají žáci spojený s fází, v níž se společně s učitelkou podílí na tom, co je v hodině řečeno. Jak je vidět z ukázky, žáci začnou říkat možné odpovědi a hlásit se ještě před tím, než ze strany učitelky zazní samotná otázka. Samotné vizuální sdělení by tak mohlo IRF strukturu dostatečně otevř́t, aniž bychom slyšeli jakýkoli dotaz.

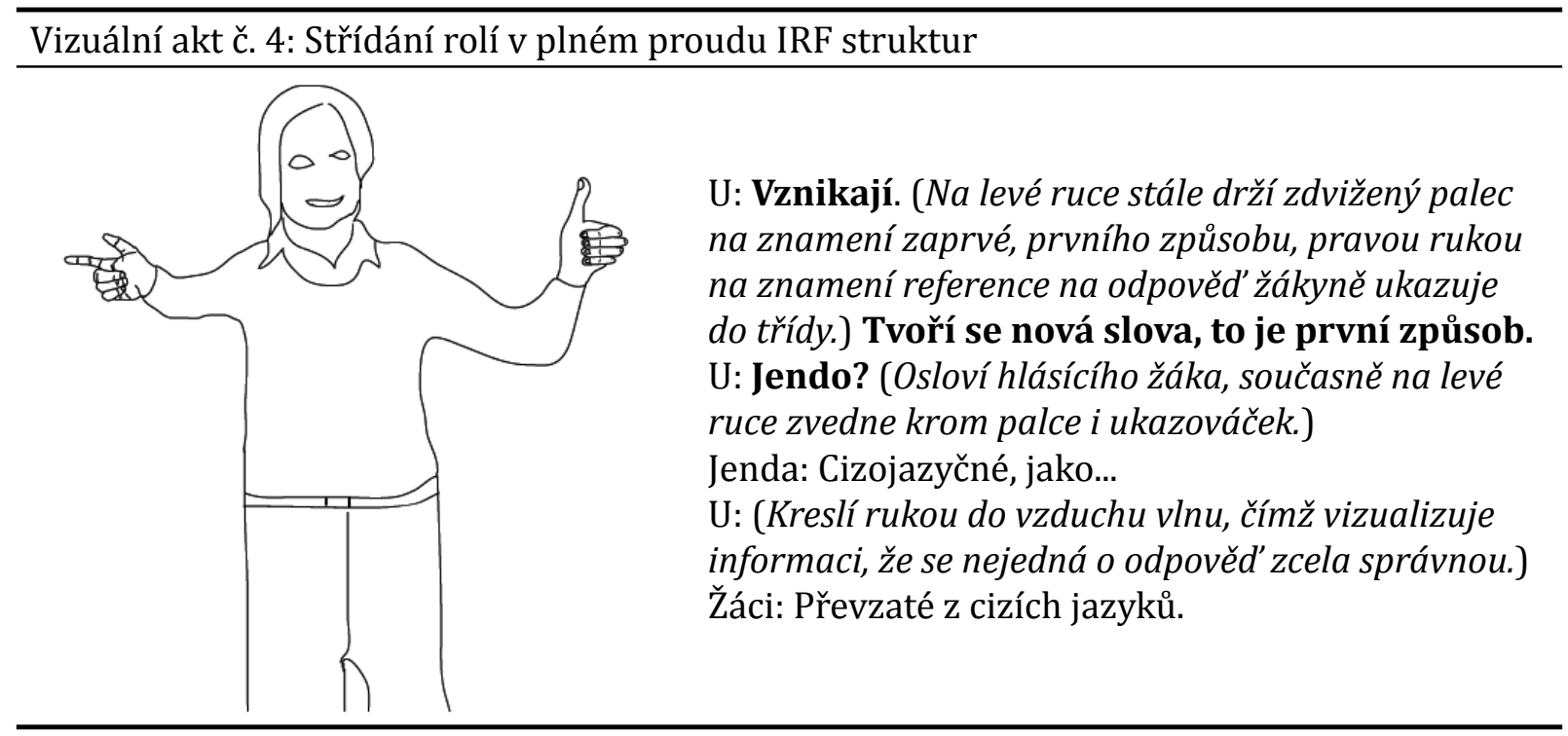

Spolu s reprodukováním IRF struktury v interaktivní fázi výuky učitelka prostor, který má před tělem uzavřený ve fázi výkladu, nadále rozevírá. I pravá ruka, která byla před první otázkou ještě natočena k tělu učitelky, nyní zcela mění svou pozici a ukazuje do třídy, jako by naznačovala osu mezi učitelkou a žáky. U učitelky Johany se jedná klíčový signál toho, že komunikační výměna mezi ní a žáky je v plném proudu. $V$ této pozici má učitelka ruku po zbytek interaktivní fáze výuky. Zamířením na konkrétního žáka přitom může funkci vizuálního sdělení rozšírít o referenci na předcházející žákovskou odpověd' (ve smyslu: „Vyjděme z toho, co již řekla Markéta."), případně může některému z žáků udělit slovo (,Jendo?"). 
Podívejme se ještě na situaci, kdy učitelka interaktivní fázi navádí zpět do fáze výkladu. Vyjdeme ze stejného tematického úseku, kdy učitelka s žáky řeší tvoření slov a hledá již poslední z možných způsobů.

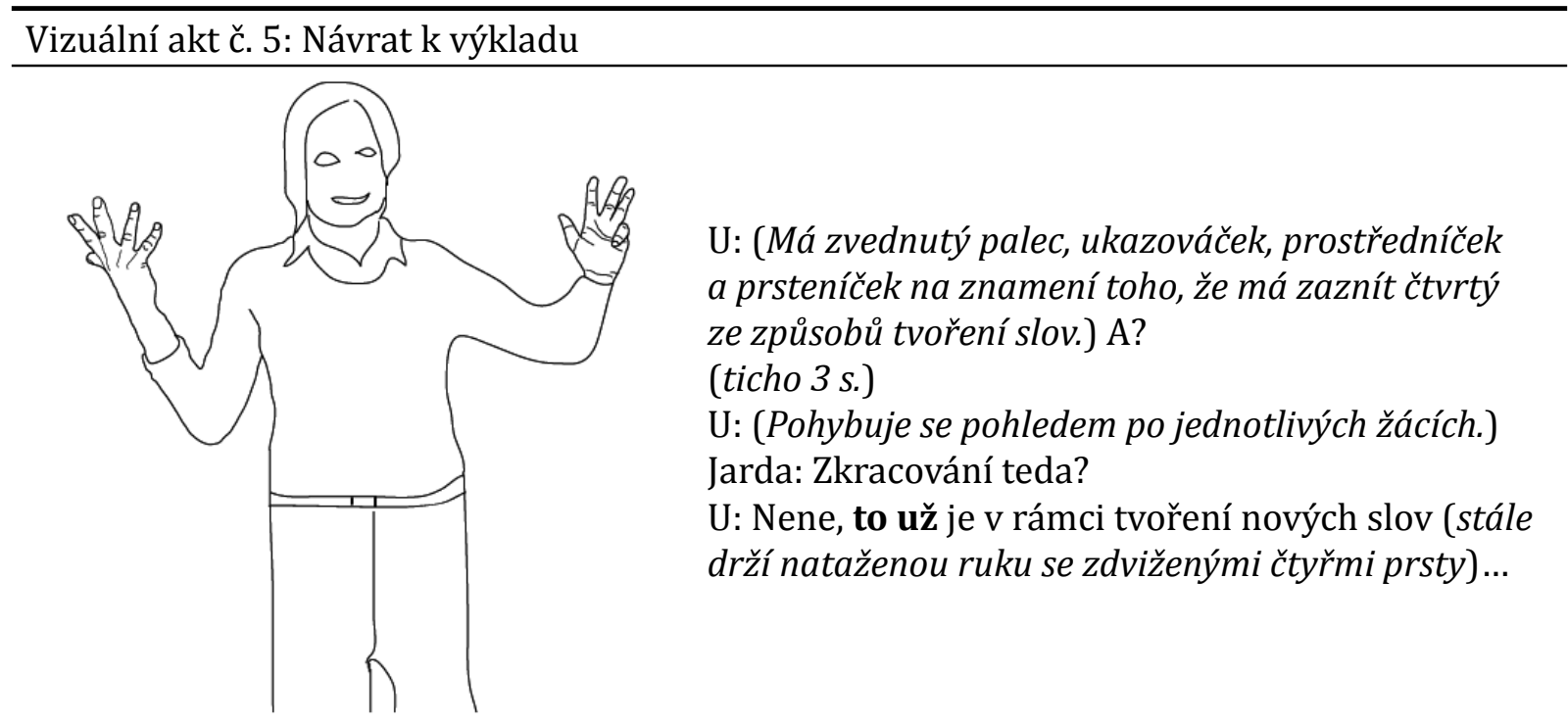

Učitelka čeká na doplnění posledního ze způsobů obohacování slovní zásoby, nicméně třívteřinové ticho, které se třídou roznese, je předznamenáním toho, že si žáci poslední ze způsobů nepamatují. Po proluce ticha se se svým tipem ozve žák Jarda, nicméně jeho odpověd' je špatná, protože se vztahuje $\mathrm{k}$ jinému učivu. Učitelka $\mathrm{v}$ tuto chvíli ohne pravou ruku, kterou do té doby vytvářela osu mezi sebou a žáky, do pomyslného signálu: Stop! a následně jí krátce mávne na znamení toho, že se nejedná o správnou odpověd'. Levá ruka se ve stejnou chvíli otáčí zpět k tělu.

Vzhledem k tomu, že i na chybnou odpověd' již učitelka poměrně dlouho čekala, dořekne správnou odpověd' sama. Sděluje, co je posledním ze způsobů tvoření nových slov, a přitom pohybem navazujícím na předcházející zamítavý signál pravé ruky postupně opíše oblouk tak, že ve výsledné pozici má obě ruce ve výši hrudníku a natočené směrem k sobě. Plynulým pohybem tak opět začíná vymezovat svůj komunikační prostor a současně přechází z IRF fáze zpět k výkladu, jako ve vizuálním aktu č. 1 .

Vrat'me se nyní k situaci, jíž jsme empirickou část této studie otevřeli. V momentě, kdy se učitelka ptala na obsah bible, stála v monologické pozici, u níž si jsou žáci vědomi, že hovoří pouze učitelka. Pokud přeci jenom v tuto chvíli chce něco slyšet ze strany žákủ, osloví jménem konkrétního žáka, který má promluvit. Je ale zcela mimo zaběhlé komunikační zvyklosti, aby učitelka 
z této pozice kladla otázku, navíc nezacílenou na jednoho žáka. Ačkoli tedy žáci odpověd' znají, doposud neobdrželi vizuální sdělení (ani verbální, ani neverbální), které by naznačovalo, že mají mluvit, a proto v tichosti očekávají, co se bude odehrávat dál. Tato situace proto může být vhodným př́íkladem toho, nakolik žáci interpretují vizuální sdělení, z nichž usuzují, kdy jim učitel dává prostor pro otázky a kdy si hlídá prostor pro svůj výklad.

\subsection{Tematické vizuální akty}

Ačkoliv jak teoretické, tak empirické texty ukazují, že gesta jsou rozšířená napříč kulturami, jen velmi málo doposud víme o tom, jak tematické vizuální akty přispívají k učení žáků a studentů. Valenzenová (Valenzeno, Alibali, \& Klatzky, 2003) dokonce tvrdí, že doposud existuje pouze několik málo výzkumů o tom, jak gesta učitele přímo ovlivňují učení studentů. My se níže pokusíme ukázat, jakou mají tematické vizuální akty podobu, jak je učitelé využívají a jaké informace jimi zprostředkovávají. Jsme si přitom vědomi toho, že je zcela nad naše možnosti ukázat, jak tato gesta ovlivňují učení žáků.

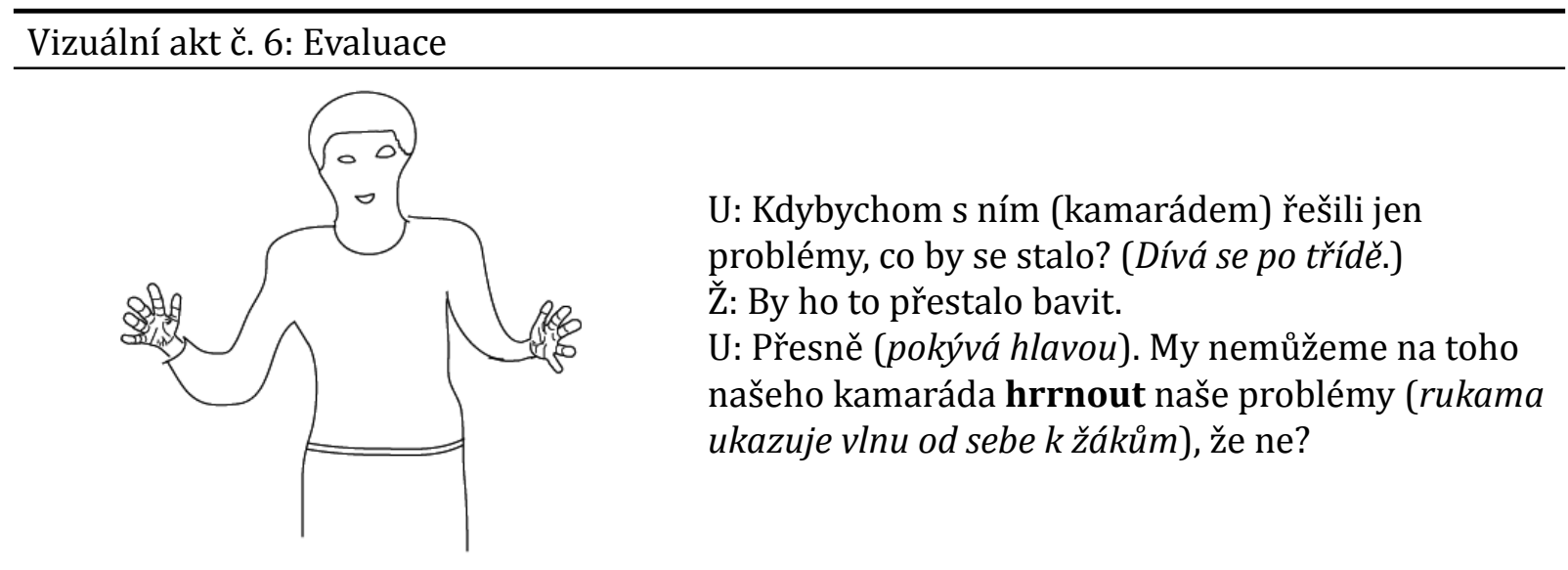

Učitelka Šárka v hodině literatury věnované antice otevírá diskusi o Aristotelově textu $O$ prátelství, který si měli žáci za domácí úkol přečíst. Právě se debatuje o tom, co je to přátelství a kamarádství, a učitelka v dialogu se žáky cizeluje charakteristiky pojmů. $V$ tomto vizuálním aktu je výrazná jak verbální promluva, kdy učitelka akcentuje a zdvojí hlásku ve slově hrrnout, tak také gesto obou paží, ve kterém učitelka kreslí pomyslnou vlnu problémů valící se na žáky. Gesto je velmi pomalé stejně jako vyslovení daného slovesa, ruce vychází od učitelského stolu, u něhož učitelka stojí, a otevírají se jako stavidlo přehrady směrem do třídy. Učitelka Šárka přitom ve vyučování zpravidla nepoužívá takto výraznou gestiku, což naznačovanou vlnu problémů ještě umocňuje. 
Vizuální akt zachycuje evaluaci učitelky na odpověd' žáka. Učitelka díky své vizuální komunikaci nejenom zdůrazňuje správnost žákovské odpovědi, ale ve své řečnické otázce, která již sama o sobě funguje jako nástroj zvýšené kontaktovosti se žáky, zviditelňuje popisovaný proces hrnutí problémů a současně tímto vizuálním aktem získává pozornost žáků.

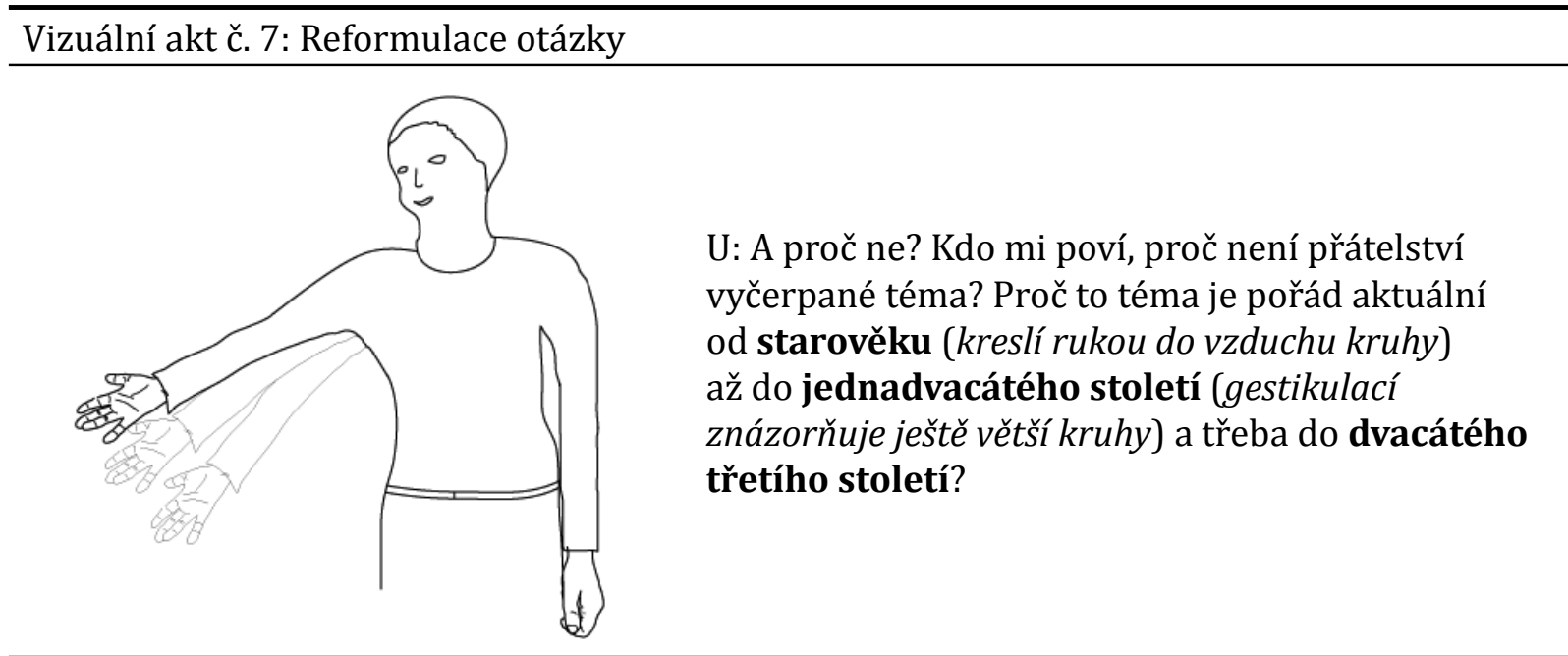

V tomto vizuálním aktu učitelka klade žákům otázku, proč je přátelství věčným literárním motivem, a po krátké odmlce ze strany žáků otázku reformuluje. Přidává k ní přitom výrazné vizuální gesto, kdy ve vzduchu před sebou odděluje pomyslné úseky dějin na časové ose, třikrát pravou a posléze jedenkrát levou rukou. Toto vizuální sdělení není jen doplňkem verbálního projevu (proč je téma aktuální) - obě paže se stávají součástí sdělení, stávají se liniemi velmi dlouhé časové osy, která visí ve vzduchu přímo před zraky žáků.

Učitelka gestem signalizuje cyklické opakování tématu v celé dosavadní lidské historii a v budoucnu. Délka tohoto trvání (resp. věčnosti přátelství jakožto tématu) je přitom demonstrována právě jejím vizuálním sdělením. Učitelka se natahuje do krajnípozice, kam jí hranice pohybu dovolí. Kruhovým pohybem na obou koncích osy svého pohybu přitom naznačuje, že trvání tématu pokračuje v obou směrech, $v$ minulosti i do budoucnosti, mnohem dál, než ona dosáhne. Věčnost je tak nejen vyslovena, ale i vizualizována $v$ tom smyslu, že sahá mnohem dál, než kam dosahuje sama učitelka. Nejedná se přitom o nápovědu ke správné odpovědi na její otázku, jako spíše o uvědomění si významu slova. 


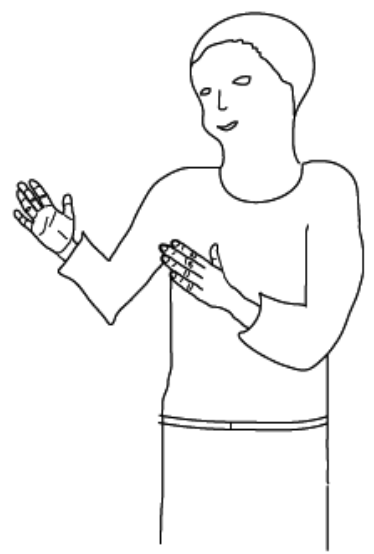

U: Skylla byla kdysi krásná dívka a ted' to bylo něco mezi drakem a psem (poutavě, tajemně, přitom se dívá po třídě), který měl šest hlav.

Vojta: To bylo něco na ostrově, ne?

U: Bylo to v úžině (oběma rukama ukazuje úžinu)..., kde byla nejdříve Skylla (ukazuje rukou), potom Charybda (stejné gesto druhou rukou). Charybda byl veliký výr, a děcka, jak to vyřešil Odysseus?

V tomto vizuálním aktu ze samého závěru hodiny vede učitelka výklad, který místy zpestřuje dramatickým projevem. Při popisu místa řekne žákům poměrně málo známý termín (úžina), který vzápětí doplňuje gestem oběma paží, kdy ve vzdálenosti 30 centimetrů od sebe ruce kreslí úzkou klikatou cestu. Pohyby rukou proti sobě přitom souběžně naznačuje dynamiku pohybu vody, která úžinou protéká. ${ }^{10}$ Posléze při vyslovení jména Skylla sáhne shora rozevřenou rukou napravo od právě vytvořené úžiny, při vyslovení jména Charybda tuto bájnou příšeru umístí stejným gestem levé ruky vlevo od úžiny. Pojem je tak vizualizován skrze gesta i verbální projev. Žáci nejenom slyší obsah části díla, které by samo o sobě bylo spletí cizích jmen a méně známé slovní zásoby, ale celou scenérii Odysseovy plavby vidí před sebou. Toto dvojí znázornění př́íběhu také plně využívají, nebot's výjimkou jednoho žáka jsou všechny oči v jinak méně pozorné třŕdě upřeny na učitelku.

Spojitost vidění a vědění, která vyplývá již z etymologie obou lexémů (obě slova totiž pocházejí ze společného základu, kdy vědět původně označovalo stav mysli, který je výsledkem vidění) a v níž má proces vidění historicky nezpochybnitelnou pozici v procesu uvědomování a vědění člověka, očividně patři $\mathrm{k}$ intuitivně používaným nástrojům, jimiž se učitelé snaží zpřístupnit žákům to, co by měli vědět. Prostřednictvím tematických sdělení totiž učitelé mohou učivo žákům předat paralelně dvěma cestami. Danými ukázkami jsme chtěli naznačit, že tematické vizuální akty se vyskytují primárně v rámci výkladu učitelů, kde se jejich prostřednictvím snaží o prohloubení porozumění obsahu určitého sdělení. $\mathrm{Z}$ empirického materiálu současně

10 Tematické vizuální akty se vyskytují jen při výkladu, objasňování a upřesňování a jak ukazuje i př́klad s úžinou, často mají úzký vztah s prostorem (viz Alibali, Kita, \& Young, 2000). 
vyplývá, že využitím zviditelňování učiva získávají pozornost žáků, která je základním předpokladem úspěšného procesu vyučování a učení.

\section{Diskuse}

Cílem předložené mikroanalýzy bylo prozkoumat procesy, které sice patří k podstatě učitelské profese (viz Valenta, 2010), ale ve studiích výukové komunikace stojí spíše na okraji zájmu. Na základě našich dat jsme poukázali na to, že vizuální významové akty ve výuce mohou mít jak interaktivní, tak tematickou povahu. Jak již v osmdesátých letech upozorňovala Cazdenová (1988), ve škole, stejně jako v jiných institucích, koexistuje jazyk kurikula a jazyk kontroly. Na předložených ukázkách jasně vidíme, že vizuální sdělení se mohou podílet jak na interaktivních vizuálních aktech (jazyk kontroly), tak mohou hrát významnou roli v tematických vizuálních aktech (jazyk kurikula).

Za jedno z hlavních zjištění vyplývajících z naší analýzy interaktivních vizuálních aktů učitele považujeme tezi o strukturaci výukové komunikace. Při opakovaném a někdy až nekonečném sledování videonahrávek výuky jsme byli překvapeni, jak je možné, že žáci poznají, jak se mají zachovat v dané situaci, ačkoli nedostávají žádné verbální pokyny. Kdybychom na zaznamenaných hodinách nebyli př́tomni nebo se $\mathrm{k}$ jejich záznamům později nevraceli, transkriptům bychom na některých místech nerozuměli. Právě interaktivní vizuální akty totiž ovlivňují, zda je situace ze strany žáků vnímána jako monologická, či dialogická. Ve třídách je právě tímto způsobem mnohdy udržována IRF struktura, i když učitel nepoloží žákům otázku, a naopak, když učitel položí otázku, nenásleduje ze strany žáků odpověd'. Mýlil se tedy Mehan (1979) a další, kteří došli k závěru, že základní bezpř́íznaková „sociální struktura" podmiňující výukovou komunikaci ve školní tř́idě se skrývá $\mathrm{v}$ triadické verbální výměně?

Myslíme si, že je nutné Mehana doplnit. Verbální projev učitele totiž není jediným na informace bohatým kanálem, který žáci přijímají - souběžně s ním sledují také vizuální sdělení učitele, prostřednictvím něhož přesně interpretují, ve které komunikační fázi se právě vyučovací hodina nachází. IRF struktura tedy není pouze určitým mechanickým principem, ale je plná individuálních projevů daného učitele. Její přítomnost je žáky trvale ověřována interpretováním vizuálních sdělení, která učitel vysílá. Tímto tedy něco k Mehanovi přidáváme, doplňujeme jej i sebe, ale neměníme. 
Druhé zjištění směřuje k povaze gest. Podle Wulfa (2010) můžeme identifikovat individuální a objektivizovanou složku gestiky. Jak jsme si ukázali na př́kladu jedné z našich učitelek, uzavřenost prostoru pro výklad učitele přitom může být signalizována např́íklad dlaněmi rukou (vizuální akt č. 1), otevřená dlaň může znamenat výzvu všem žákům $\mathrm{k}$ zapojení se do dialogu (vizuální akt č. 3), což se může rychle změnit do adresného vyvolání určitého jedince, když se otevřená dlaň mění v ukazovací gesto (vizuální akt č. 4). Pozice učitele před jeho stolem může znamenat jak začátek nového tématu, tak také začátek diktování zápisu do sešitu. Přes individuální způsob konstruování vizuálních sdělení však vizuální komunikace učitelů obsahuje tytéž vzorce, které jsme ilustrovali na př́padu učitelky Johany. Strukturace výukové komunikace skrze interaktivní vizuální akty se přitom odehrává v cyklech opakujících se v průběhu celé vyučovací hodiny.

Situace, kdy učitelé a žáci interpretují interaktivní vizuální sdělení ve shodě, je pro učitele velmi dobrým výsledkem. Vizuální fázování výuky je totiž úzce provázáno se strukturou verbální složky a do značné míry rozhoduje o tom, jak bude verbální komunikace interpretována. Pokud tedy žáci na vizuální sdělení učitele ustáleně reagují, znamená to, že jsou spolu s žáky naladěni na stejný způsob práce a že žáci jsou schopni na sebemenší signály učitele reagovat, což je ve chvíli, kdy má učitel ve třídě dvacet žáků, nesmírně důležité. $V$ našich datech jsme mohli pozorovat jeden př́ípad, kdy to tak naopak vůbec nefungovalo, protože učitel neměl ustálené vizuálně demonstrované komunikační rituály. Interakci otevíral v různých vizuálních aktech, jejichž sdělení bylo stejné jako pro ostatní fáze výuky. Opakovaně se pak stává, že žáci „skočí do řeči“, nebot’ situaci interpretují jako signál, že mají hovořit, a naopak, že na položenou otázku nikdo neodpovídá, protože se žáci domnívají, že se jedná o fázi, v níž mluví učitel. Vzhledem k tomu, že ve třídě po stránce ustanovení komunikační formy dochází k neustálé disonanci, je ve třídě komplikovaný také proces učení.

Převaha ryze individuálních gest, která jsou však žáky čitelná a reflektovaná, znamená pro nás jakožto badatele nutnost doslova mravenčí práce, nicméně je znakem profesní identity daného učitele (Švaříček, 2011b). Učitel Karel se často pohybuje po třídě a s oblibou lamentuje rukama. Eva, Šárka a Marcela sází na oční kontakt a využívají prostoru (ve chvíli, kdy učitelky stojí za katedrou, žáci vědí, že výuka je ve fázi výkladu, do níž oni sami jako pravomocní mluvčí zkrátka nevstupují, nebo alespoň vstupovat nemají). U učitele Jana je interpretačním vodítkem vedle postoje těla a jeho umístění v prostoru třídy povaha očního kontaktu s žáky apod. 
Třetí zjištění se týká způsobů, jakým jsou vizuální sdělení zprostředkovávána žákům. Jak ukazují vizuální akty z vyučovacích hodin, učitelé využívají jak tělesného pohybu, tak gestikulace rukou k vyjádření určitého obsahu. Obě učitelky na podlaze třídy kreslí svým pohybem imaginární trojúhelník, který často dále doprovází gesty rukou. Tento didaktický trojúhelník u obou našich popsaných učitelek vypadá následovně: Učitel stojí zády k tabuli před první prostřední lavicí, svojí pravou rukou pomyslně přivádí žáky k vědění, které je symbolizováno levou rukou (ukazuje na tabuli, odpočítává příklady, ukazuje abstraktní pojmy apod.). V tomto postoji je však učitel stále otočen tváří ke třídě a vytváří tak svými pažemi trojúhelník spojující učivo, žáky a učitele. Obsah je pomyslným darem, který učitel žákovi předává.

Čtvrtý nález se vztahuje k povaze tematických aktů. Tematické vizuální akty učiteli napomáhají především ve výkladu žákům, kde jejich prostřednictvím může zdůrazňovat jednotlivé informace, vizualizovat či zdůrazňovat jejich význam. ${ }^{11} \mathrm{~V}$ tomto smyslu hrají tematické akty významnou roli při konceptualizaci sdělení, které jedinec verbalizuje. Z toho vyplývá, že gesta hrají roli nejenom při sdělování informace, ale také při kognitivní konceptualizaci. ${ }^{12}$ Dovolujeme si obrazně říci, že "gesta uvolňují ruce“: učitel má díky materializaci objektu skrze gesto více mentální kapacity k verbální konceptualizaci. Nelze přitom říci, že by gesta odkazovala k nějakému implicitnímu poznání, nebot' učitel skrze gesta dokáže vyjádřit určitou myšlenku, popsat ji verbálně a následně s ní pracovat, jak vidíme např́ílad u vizuálního aktu č. 7 . V tom nacházíme také zpětné zdůvodnění zaměření se výzkumu na vizuální významové akty, které obsahují dva paralelní kanály informací. Jak připomínají Garber a jeho kolegyně (1998), poznatky, které jsou předávány skrze gesta, nejsou svázány rukama, nebot' obsah těchto poznatků může učitel dále komentovat verbálně.

Při interpretaci dat jsme také zjistili, že není možné význam vizuálního významového aktu posuzovat pouze na základě jednoho jevu, například skrze pohyb učitele. Tělo a gesta mohou totiž být v rozporu, jak je vidět ve vizuálním aktu č. 1, kdy učitelka Johana stojí na okraji stupínku, tělem dává najevo blízkost žákům, ale gestem dlaní uzavírá žákům prostor. Toto páté zjištění dokládá, že význam vizuálního aktu není dán dopředu, není dán pouze

11 Problematice žákovských gest a jejich významu pro myšlení se věnujeme v jiném textu (Šalamounová, 2013).

12 O hledání významu skrytého ve výrazu učitele odhalujícího jeho skryté subjektivní představy viz Janík \& Slavík (2009). 
povahou gest a ani významem slov. Jedná se o celek plus kontext. Výuková komunikace je mnohem více než jen slova, čímž bychom chtěli doplnit také rejstřík našich dosavadních výzkumných závěrů.

\section{Poděkování}

Autoři děkují učitelům a žákům, kteří svolili k výzkumu, a všem kolegům, kteří nám pomáhali se sběrem dat. Dále děkujeme Kláře Šed’ové a dvěma anonymním recenzentům za jejich komentáře k předchozí verzi textu.

\section{Literatura}

Alexander, R. (2006). Towards dialogic teaching: Rethinking classroom talk. Cambridge: Dialogos.

Alibali, M. W., Kita S., \& Young, A. J. (2000). Gesture and the process of speech production: We think, therefore we gesture. Language and Cognitive Processes, 15(6), 593-613.

Becvar, A. L., Hollan J., \& Hutchins, E. (2005). Hands as molecules: Representational gestures used for developing theory in a scientific laboratory. Semiotica, 156(1), 89-112.

Bavelas, J. B. (1994). Gestures as part of speech: Methodological implications. Research on Language and Social Interaction, 27(3), 201-221.

Bavelas, J. B., \& Chovil, N. (2000). Visible acts of meaning. An integrated message model of language use in face-to-face dialogue. Journal of Language and Social Psychology, 19(2), 163-194.

Bavelas, J. B., Chovil, N., Coates, L., \& Roe, L. (1995). Gestures specialized for dialogue. Personality and Social Psychology Bulletin, 21(4), 394-405.

Bavelas, J. B., Gerwing, G., Allison, M., \& Sutton, C. (2011). Dyadic evidence for grounding with abstract deictic gestures. In G. Stam \& M. Ishino (Eds.), Integrating gestures: The interdisciplinary nature of gesture (s. 49-60). Amsterdam: Benjamins.

Cazden, C. B. (1988). Classroom discourse. The language of teaching and learning. Portsmouth: Heineman.

DeVito, J. A. (2008). Základy mezilidské komunikace. Praha: Grada.

Flanders, N. (1970). Analysing teaching behavior. Reading: Addison-Wesley.

Garber, P., Wagner Alibali, M., \& Goldin-Meadow, S. (1998). Knowledge conveyed in gesture is not tied to the hands. Child Development, 69(1), 75-84.

Hackl, B., \& Hummel, S. (2011). Velikonoční prázdniny: co se lze ve škole naučit z řeči těla. Studia paedagogica, 16(1), 137-160.

Hattie, J. A. C. (2009). Visible learning. A synthesis of over 800 meta-analyses relating to achievement. New York: Routledge.

Janík, T., \& Slavík, J. (2009). Obsah, subjekt a intersubjektivita v oborových didaktikách. Pedagogika, 59(2), 116-135.

Kita, S. (2000). How representational gestures help speaking. In D. Mcneill (Ed.), Language and gesture (s. 162-185). Cambridge: Cambridge University Press. 
Klinzing, H. G., \& Jackson, I. (1987). Training teachers in nonverbal sensitivity and nonverbal behavior. International Journal of Educational Research, 11(5), 589-600.

Mehan, H. (1979). Learning lessons: Social organisation in the classroom. Cambridge: Harvard University Press.

McNeill, D. (1992). Hand and mind: What gestures reveal about thought. Chicago: University of Chicago Press.

Neill, S. (1991). Classroom nonverbal communication. London: Routledge.

Nystrand, M., Gamoran, A., Kachur, R., \& Prendergast, C. (1997). Opening dialogue. Understanding the dynamics of language and learning in the English classroom. New York, London: Teachers College Press.

Reinhard, M.-A., \& Sporer, S. L. (2008). Verbal and nonverbal behaviour as a basis for credibility attribution: The impact of task involvement and cognitive capacity. Journal of Experimental Social Psychology, 44(3), 477-488.

Reynolds, F. J., \& Reeve, R. A. (2002). Gesture in collaborative mathematics problem-solving. Journal of Mathematical Behavior, 21(4), 447-460.

Roth, W.-M. (2001). Gestures: Their role in teaching and learning. Review of Educational Research, 71(3), 365-392.

Schrober, M. F., \& Clark, H. H. (1989). Understanding by addressees and overhearers. Cognitive Psychology, 21(2), 211-232.

Šalamounová, Z. (2013). Čtení z rukou - gestika jako nástroj zviditelňování myšlení. Studia paedagogica, 18(1), ( $v$ tisku).

Šed'ová, K., \& Švaříček, R. (2010). Zamlčené hodnocení: zpětná vazba ve výukové komunikaci na druhém stupni základní školy. Studia paedagogica, 15(2), 61-86.

Šed'ová, K., Švaříček, R., \& Šalamounová, Z. (2012). Komunikace ve školní třídě. Praha: Portál.

Švaříček, R. (2011a). Funkce učitelských otázek ve výukové komunikaci na druhém stupni základní školy. Studia paedagogica, 16(1), 9-46.

Švaříček, R. (2011b). Zlomové události při vytváření profesní identity učitele. Pedagogika.sk, 2(4), 247-274.

Valenta, J. (2010). Scénická dimenze výkonu učitelské profese. Pedagogika, 60(2), 104-114.

Valenzeno, L., Alibali, M. W., \& Klatzky, R. (2003). Teachers gestures facilitate students learning: A lesson in symmetry. Contemporary Educational Psychology, 28(2), 187-204.

Wulf, Ch. (2010). Ritual and identity: The staging and performing of rituals in the lives of young people. London: Tufnell Press.

\section{Autoři}

Mgr. Roman Švaříček, Ph.D., Masarykova univerzita, Filozofická fakulta, Ústav pedagogických věd, Arna Nováka 1, 60200 Brno, e-mail: svaricek@phil.muni.cz

Mgr. Zuzana Šalamounová, Masarykova univerzita, Pedagogická fakulta, Katedra pedagogiky, Poříćí 7, 60300 Brno, e-mail: salamounova@ped.muni.cz 


\section{Visual acts in instructional communication}

Abstract: This empirical study describes the functions of visual acts of meaning in the educational communication between teachers and their pupils. The study understands visual acts to be visual messages that have meaning for participants of communication. The data was gathered through direct observation of 32 classes of humanities subjects at lower secondary schools. Visual acts were firstly divided into topic visual acts (which convey events, objects or thoughts directly related to the topic of conversation) and interactive visual acts (which can be characterized as contact messages). In the context of lessons, topic visual acts are presented as a tool for conceptualisation of educational content. On the other side, interactive visual acts are described as a mechanism which participates in establishing the setting of educational communication. Although visual acts of meaning often have the same functions and structure, it transpires that their nature is highly individualized and it can be seen as a sign of a teacher's professional identity.

Keywords: instructional communication, educational communication, visual acts of meaning, verbal communication, non-verbal communication, IRF exchange structure

Saxonberg S., \& Hašková H. (Eds.). (2012). Péče o předškolní děti: boření mýtů. Praha: SLON.

Málokterá oblast veřejné politiky je opředena tolika mýty jako péče o předškolní děti. Tyto mýty znemožňují potřebné změny rodinné politiky, nebot' blokují rozvoj racionální společenské diskuse, která by se neopírala o ideologické argumenty, ale o poznatky soudobých mezinárodně uznávaných vědeckých studií. Cílem knihy je odhalit a diskreditovat ty mýty, které na české politické a mediální scéně neustále přežívají a blokují otevřenou společenskou a politickou diskusi i reformu rodinné politiky tak, aby odpovídala potřebám různých typů rodin i jejich jednotlivých členů. Autoři v knize konkrétně hledají odpověd’ na tyto otázky: Jsou zařízení péče o děti mladší tří let škodlivá? Co říká současný mezinárodní výzkum o dopadech těchto zařízení na dlouhodobý vývoj a pozdější společenské uplatnění dětí, které je navštěvují? Kde se vzala magická hranice tří let? Prokázali čeští psychologové, že jesle malé děti poškozují? Vymysleli jesle komunisté? Je přirozené, aby byly děti mladší tř́ let $\mathrm{v}$ celodenní péči jejich matek? Proč Češi nechtějí zařízení péče o děti mladší tř̌i let? A opravdu je nechtějí? Je pravdou, že si Česká republika nemůže finanční investice do zařízení péče o děti mladší tř́ let dovolit? Jakou cenu ve skutečnosti platí Češi za jejich nedostupnost? Vychází česká rodinná politika z odborných poznatků? Jak by měla vypadat politika péče o předškolní děti v České republice? 